\title{
PERTUMBUHAN EKONOMI DAN KETIMPANGAN PENDAPATAN DI PROVINSI BENGKULU
}

\author{
Rahmat Al Hidayat ${ }^{1}$ \\ ${ }^{1}$ Sekolah Tinggi Ilmu Administrasi Bengkulu \\ e-mail: yynrahmad@gmail.com
}

\begin{abstract}
ABSTRAK
Penelitian ini bertujuan untuk menganalisis tipologi daerah antarkabupaten/kota di Provinsi Bengkulu, menganalisis ketimpangan pembangunan antarkabupaten/kota di Provinsi Bengkulu, menganalisis apakah hipotesis Kuznets (kurva $U$ terbalik) berlaku di Provinsi Bengkulu, menganalisis faktor-faktor yang mempengaruhi pertumbuhan PDRB per kapita di Provinsi Bengkulu. Data yang digunakan dalam penelitian ini adalah data sekunder dari $10 \mathrm{kabupaten/kota} \mathrm{di}$ Provinsi Bengkulu selama periode 2005-2009 dengan menggunakan alat analisis tipologi Kassen, indeks Williamson, hipotesis Kuznets, dan regresi panel data. Hasil analisis dengan tipologi Klassen dapat disimpulkan bahwa klasifikasi daerah di Provinsi Bengkulu dapat dibedakan menjadi, 1) Daerah cepat maju dan cepat tumbuh, yaitu Kota Bengkulu, Kabupaten Rejang Lebong, Kabupaten Kepahiang, dan Kabupaten Lebong; 2) Daerah maju tapi tertekan, yaitu Kabupaten Bengkulu Tengah; 3) Daerah berkembang cepat, yaitu Kabupaten Bengkulu Selatan, Kabupaten Kaur, Kabupaten Seluma, dan Kabupaten Mukomuko; 4) Daerah relatif tertinggal, yaitu Kabupaten Bengkulu Utara. Berdasarkan hasil analisis indeks Williamson menunjukkan bahwa ketimpangan pendapatan antarkabupaten/kota di Provinsi Bengkulu selama periode penelitian 2005-2009 berfluktuatif dengan ketimpangan rata-rata 0,39. Berdasarkan hipotesis Kuznets selam periode 2005-2009 membuktikan bahwa hipotesis Kuznets berlaku di Provinsi Bengkulu. Berdasarkan hasil regresi data panel menunjukkan bahwa pertanian berpengaruh postif dan signifikan, jumlah penduduk berpengaruh positif dan signifikan, dan tenaga kerja berpengaruh negatif dan signifikan terhadap pertumbuhan PDRB per kapita di Provinsi Bengkulu.
\end{abstract}

Kata Kunci: Ketimpangan, Pertumbuhan, Tipologi Klassen, Indeks Williamson, Hipotesis Kuznets, Regresi Panel Data.

\begin{abstract}
This study aims to analyze the regional typology between districts / cities in Bengkulu Province, analyze development disparities between districts / cities in Bengkulu Province, analyze whether the Kuznets hypothesis (inverted U curve) applies in Bengkulu Province, analyze the factors that affect per capita GRDP growth in the Province Bengkulu. The data used in this study are secondary data from 10 districts / cities in Bengkulu Province during the period 2005-2009 using Kassen typology analysis tools, Williamson index, Kuznets hypothesis, and panel data regression. The results of the analysis with Klassen typology can be concluded that the classification of regions in Bengkulu Province can be divided into: 1) Fast-growing and fast-growing regions, namely Bengkulu City, Rejang Lebong Regency, Kepahiang Regency, and Lebong Regency; 2) Developed but depressed
\end{abstract}


regions, namely Bengkulu Tengah Regency; 3) Fast developing regions, namely South Bengkulu Regency, Kaur Regency, Seluma Regency and Mukomuko Regency; 4) The region is relatively underdeveloped, namely North Bengkulu Regency. Based on the results of Williamson index analysis, it shows that income inequality between districts / cities in Bengkulu Province during the 2005-2009 research period fluctuated with an average inequality of 0.39. Based on the Kuznets hypothesis during the period 2005-2009 it proved that the Kuznets hypothesis was valid in Bengkulu Province. Based on the results of panel data regression, it shows that agriculture has a positive and significant effect, population has a positive and significant effect, and labor has a negative and significant effect on the growth of GDP per capita in Bengkulu Province.

\section{Keywords: Inequality, Growth, Klassen Typology, Williamson Index, Kuznets Hypothesis, Panel Data Regression.}

\section{PENDAHULUAN}

Pembangunan ekonomi suatu daerah pada hakekatnya merupakan suatu rangkaian kegiatan yang dilaksanakan secara sadar dan terus menerus untuk mewujudkan keadaan yang lebih baik secara bersama-sama dan berkesinambungan. Dalam kerangka itu, pembangunan ekonomi juga untuk memacu pemerataan pembangunan dan hasil-hasilnya dalam rangka meningkatkan kesejahteraan rakyat secara adil dan merata. Salah satu tolok ukur penting dalam menentukan keberhasilan pembangunan ekonomi nasional atau wilayah adalah tingkat pertumbuhan ekonomi. Pertumbuhan ekonomi menggambarkan suatu dampak nyata dari kebijakkan pembangunan yang dilaksanakan khususnya dalam bidang ekonomi, sehingga menurut Meier dan Raunch (2005: 6975), pertumbuhan ekonomi merupakan bagian dari pembangunan ekonomi. Tanpa adanya pertumbuhan ekonomi, maka pembangunan ekonomi kurang bermakna.

Pertumbuhan ekonomi selalu dikaitkan dengan peningkatan produksi barang dan jasa yang diukur dengan kenaikan Produk Domestik Bruto (PDB), untuk melihat apakah terjadi pertumbuhan dalam struktur ekonomi. Pertumbuhan ekonomi suatu daerah biasanya dapat dilihat dari adanya peningkatan Produk Domestik Regional Bruto (PDRB), yang merupakan alat ukur atau indikator yang digunakan untuk mengukur dan menganalisis perkembangan dan pertumbuhan ekonomi suatu daerah (Arsyad, 2005: 108). Indikator lainnya yang sering digunakan untuk mengukur tingkat kemajuan pembangunan adalah tingkat pertumbuhan pendapatan per kapita. Indikator tersebut digunakan untuk mengukur kemampuan suatu negara untuk memperbesar outputnya dibandingkan dengan tingkat pertumbuhan penduduknya. Laju pertumbuhan PDRB per kapita riil sering digunakan untuk mengukur sejauh mana tingkat kemakmuran ekonomi suatu bangsa secara keseluruhan yakni seberapa banyak barang dan jasa yang tersedia bagi rata-rata penduduk untuk melakukan konsumsi dan investasi.

Meski kegiatan pembangunan dilaksanakan melalui berbagai penyempurnaan, namun masih banyak terjadi ketimpangan-ketimpangan secara sosial ekonomi. Ketimpangan tersebut akan dapat menciptakan kelompok-kelompok masyarakat yang tidak memiliki kemampuan untuk mengakses sumber-sumber daya pembangunan. Pembangunan yang telah dilakukan selama ini secara umum belum mampu meningkatkan taraf hidup dan kesejahteraan masyarakat. Oleh karena itu, pembahasan tentang struktur dan faktor penentu pertumbuhan daerah akan sangat penting artinya 
bagi pemerintah daerah dalam menentukan upaya-upaya yang dapat dilakukan untuk mendorong pertumbuhan ekonomi di daerahnya (Syafrizal, 2008: 86). Provinsi Bengkulu dengan luas 19.788,7 $\mathrm{Km} 2$ yang terletak di bagian barat Pulau Sumatera dengan Bengkulu sebagai ibu kota provinsi. Secara administratif terdiri dari 9 (sembilan) kabupaten dan 1 (satu) kota dengan jumlah penduduk pada tahun 2010 tercatat sebanyak 1.715 .518 jiwa.

Pertumbuhan ekonomi Provinsi Bengkulu sebagai salah satu indikator keberhasilan pembangunan yang diukur dengan Produk Domestik Regional Bruto (PDRB) selama lima tahun (2005-2009). Berdasarkan pada tabel 1.1 dapat dilihat bahwa pertumbuhan ekonomi Provinsi Bengkulu masih mengalami fluktuasi, laju pertumbuhan ekonomi tertinggi terjadi pada tahun 2007 sebesar 6,03 persen dan terendah pada tahun 2009 sebesar 4,04 persen. Pembangunan ekonomi daerah telah berhasil menciptakan laju pertumbuhan rata-rata sebesar 5,44 persen yang dapat dilihat pada tabel 1.1 berikut.

Tabel 1.1

PDRB dan Pertumbuhan Ekonomi Provinsi Bengkulu Atas Dasar Harga Konstan 2000 Menurut Provinsi, 2005-2009

\begin{tabular}{|c|c|c|}
\hline \multirow{2}{*}{ Tahun } & \multicolumn{2}{|c|}{ Bengkulu } \\
\cline { 2 - 3 } & $\begin{array}{c}\text { PDRB } \\
\text { (Juta Rp) }\end{array}$ & $\begin{array}{c}\text { Pertumbuhan } \\
(\%)\end{array}$ \\
\hline 2005 & $6.239 .364,35$ & 5,82 \\
\hline 2006 & $6.610 .625,72$ & 5,95 \\
\hline 2007 & $7.008 .964,56$ & 6,03 \\
\hline 2008 & $7.384 .029,00$ & 5,35 \\
\hline 2009 & $7.682 .081,00$ & 4,04 \\
\hline \multicolumn{2}{|c|}{ Rata-rata } & 5,44 \\
\hline
\end{tabular}

Sumber: BPS Pusat, 2010 (data diolah)

Keberhasilan pembangunan ekonomi Provinsi Bengkulu tidak terlepas dari keberhasilan pembangunan kabupaten/kota yang ada. Keberhasilan ekonomi ini dapat dilihat dari pertumbuhan PDRB masing-masing daerah. Semakin tinggi pertumbuhan PDRB kabupaten/kota maka semakin besar kontribusinya terhadap pertumbuhan ekonomi provinsi, sebaliknya bila pertumbuhan PDRB kabupaten/kota mengalami penurunan, maka kontribusi daerah tersebut sangat kecil terhadap pertumbuhan ekonomi provinsi

Tabel 1.2

PDRB Provinsi Bengkulu Atas Dasar Harga Konstan 2000 Menurut Kabupaten/Kota, 20052009 (juta rupiah)

\begin{tabular}{|l|r|r|r|r|r|}
\hline $\begin{array}{l}\text { Kabupaten/ } \\
\text { Kota }\end{array}$ & 2005 & 2006 & 2007 & \multicolumn{1}{c|}{2008} & \multicolumn{1}{c|}{2009} \\
\hline Bengkulu Selatan & $436.903,00$ & $462.729,00$ & $491.283,00$ & $515.176,00$ & $538.344,00$ \\
\hline Rejang Lebong & $1.308 .372,00$ & $1.381 .451,00$ & $1.466 .297,00$ & $1.548 .697,00$ & $1.626 .312,00$ \\
\hline Bengkulu utara & $909.210,94$ & $966.925,00$ & $1.019 .557,96$ & $731.037,55$ & $766.318,62$ \\
\hline Seluma & $195.505,00$ & $204.681,45$ & $214.194,63$ & $225.858,76$ & $235.573,27$ \\
\hline
\end{tabular}




\begin{tabular}{|l|r|r|r|r|r|}
\hline Kaur & $267.894,00$ & $284.862,00$ & $303.926,07$ & $321.457,59$ & $337.659,33$ \\
\hline Muko-Muko & $440.020,72$ & $464.751,00$ & $487.851,00$ & $510.069,00$ & $533.775,79$ \\
\hline Lebong & $402.784,00$ & $424.260,00$ & $445.941,00$ & $468.202,00$ & $489.657,00$ \\
\hline Kepahiang & $564.688,00$ & $595.272,00$ & $633.248,00$ & $667.782,00$ & $698.525,00$ \\
\hline Bengkulu tengah & 0 & 0 & 0 & $352.024,99$ & $366.032,84$ \\
\hline Kota bengkulu & $1.589 .060,00$ & $1.694 .654,66$ & $1.806 .943,00$ & $1.898 .190,10$ & $1.998 .432,64$ \\
\hline
\end{tabular}

Sumber: BPS Provinsi Bengkulu (2010)

Pertumbuhan ekonomi di Provinsi Bengkulu periode 2005-2009 sebagaiman ditunjukkan pada tabel 1.2, masih didominasi oleh beberapa kabupaten saja. Ada daerah yang memiliki jumlah PDRB yang besar, seperti Kota Bengkulu, Kabupaten Rejang Lebong, dan Kabupaten Bengkulu Utara, sedangkan daerah yang memiliki jumlah PDRB yang kecil, seperti Kabupaten Kaur dan Kabupaten Seluma. Hal ini mengisyaratkan bahwa masih terjadi ketimpangan antar daerah di Provinsi Bengkulu. Dari ulasan di atas, penulis tertarik untuk meneliti tentang "Pertumbuhan Ekonomi Dan Ketimpangan Pendapatan Di Provinsi Bengkulu". Berdasarkan latar belakang di atas, maka permasalahan yang dapat dirumuskan dalam penelitian ini adalah sebagai berikut:

a. Bagaimanakah pengklasifikasian perekonomian antarkabupaten/kota berdasarkan pertumbuhan ekonomi dan PDRB per kapita di Provinsi Bengkulu pada periode 2005 sampai 2009 ?

b. Apakah dengan laju pertumbuhan PDRB per kapita yang tinggi masih terjadinya ketimpangan pertumbuhan ekonomi antar kabupaten/kota di Provinsi Bengkulu ?

c. Apakah faktor-faktor pertanian, indeks pembangunan manusia, jumlah penduduk, jumlah tenaga kerja, dan pengeluaran pemerintah mempengaruhi pertumbuhan PDRB per kapita di Provinsi Bengkulu

Sedangkan penelitian bertujuan untuk Mengklasifikasi kabupaten/kota berdasarkan laju pertumbuhan ekonomi dan PDRB per kapita di Provinsi Bengkulu., Menganalisis ketimpangan pembangunan dan pertumbuhan PDRB per kapita (hipotesis Kuznets tentang U-terbalik) antarkabupaten/kota di Provinsi Bengkulu, serta Menganalisis faktor-faktor yang mempengaruhi pertumbuhan PDRB per kapita di Provinsi Bengkulu. Sehingga dari tujuan penelitian tersebut makan penelitian ini diharapkan bermanfaat untuk:

a. Kegunaan Akademis

i. Sebagai bahan kajian dan sumbangan pemikiran dalam peningkatan laju pertumbuhan ekonomi dan PDRB per kapita.

ii. Sebagai bahan referensi bagi peneliti lain apabila berminat mengulas permasalahan yang sama.

b. Kegunaan Praktis

i. Masukan bagi Pemerintah Provinsi Bengkulu dalam mengambil kebijakan.

ii. Sarana sosialisasi mengenai pertumbuhan ekonomi regional sebagai upaya peningkatan laju pertumbuhan ekonomi dan PDRB per kapita. 


\section{TINJAUAN LITERATUR Pembangunan Ekonomi}

Pembangunan ekonomi pada hakikatnya adalah serangkaian usaha dan kebijaksanaan yang bertujuan untuk meningkatkan taraf hidup masyarakat, memperluas lapangan kerja, memeratakan pembagian pendapatan, meningkatkan hubungan ekonomi regional dan internasional melalui pergeseran struktur kegiatan ekonomi dari sektor primer ke sektor sekunder dan tersier. Jadi arah dari pembangunan ekonomi adalah mengusahakan agar pendapatan masyarakat naik, disertai dengan tingkat pemerataan yang sebaik mungkin (Widodo, 2006: 75). Permasalahan yang sering muncul dalam pembangunan ekonomi adalah terjadinya disparitas atau ketimpangan daerah satu dengan lainnya. Williamson (1965) meneliti hubungan antardisparitas regional dengan tingkat pembangunan ekonomi, dengan menggunakan data ekonomi negara yang sudah maju dan yang sedang berkembang. Ditemukan bahwa selama tahap awal pembangunan, disparitas regional menjadi lebih besar dan pembangunan terkonsentrasi di daerah-daerah tertentu. Pada tahap yang lebih matang dari pertumbuhan ekonomi tampak adanya keseimbangan antardaerah dan disparitas berkurang dengan signifikan (lihat Kuncoro, 2004: 133).

Derajat disparitas yang tinggi dapat menyebabkan timbulnya permasalahan antara lain terjadinya ketidakseimbangan aktivitas perekonomian masyarakat dalam suatu kawasan yang cenderung akan terkonsentrasi pada daerah-daerah relatif maju. Menurut Syafrizal (2008: 117-121) faktor utama terjadinya disparitas antardaerah yaitu perbedaan sumber daya, perbedaan kondisi demografis, kurang lancarnya mobilitas barang dan jasa, konsentrasi kegiatan ekonomi wilayah dan alokasi dana pembangunan antardaerah.

\section{Teori pertumbuhan ekonomi dan PDRB}

Pertumbuhan ekonomi adalah proses kenaikan output per kapita dalam jangka panjang. Pertumbuhan ekonomi sebagai suatu proses melihat aspek dinamis dari suatu perekonomian yaitu melihat bagaimana suatu perekonomian berkembang atau berubah dari waktu ke waktu. Pertumbuhan ekonomi berkaitan dengan kenaikan output per kapita, artinya harus mampu menjelaskan apa yang terjadi dengan GDP total dan apa yang terjadi dengan jumlah penduduk. Aspek ketiga dari definisi pertumbuhan ekonomi adalah perspektif waktu jangka panjang yang dapat diartikan bahwa proses pertumbuhan ekonomi harus bersifat self-generating, yang berarti bahwa proses itu sendiri menolak kekuatan atau momentum bagi timbulnya kelanjutan pertumbuhan tersebut dalam periode-periode selanjutnya (Boediono, 1999: 1-2).

\section{Ketimpangan pembangunan daerah}

Ketimpangan pembangunan daerah selalu muncul dan cenderung semakin melebar. Fenomena yang dijelaskan oleh Myrdal sebagai akibat dari proses penyebab akumulatif. Menurut Myrdal (1957 dalam Arsyad, 2005: 129) perbedaan tingkat kemajuan ekonomi antardaerah yang berlebihan akan menyebabkan pengaruh yang merugikan (backwash effects) mendominasi pengaruh yang menguntungkan (spread effects) terhadap pertumbuhan daerah, dalam hal ini mengakibatkan proses ketidakseimbangan. Pelaku-pelaku yang mempunyai kekuatan di pasar secara normal akan cenderung meningkat bukannya menurun, sehingga mengakibatkan ketimpangan antardaerah. 


\section{Pengeluaran pembangunan}

Pengeluaran pemerintah (goverment expenditure) adalah bagian dari kebijakan fiskal (Sukirno, 1999: 151) yakni suatu tindakan pemerintah untuk mengatur jalannya perekonomian dengan cara menentukan besarnya penerimaan dan pengeluaran pemerintah tiap tahunnya yang tercermin dalam dokumen APBN untuk nasional dan APBD untuk daerah atau regional. Tujuan dari kebijakan fiskal ini adalah dalam rangka menstabilkan harga, tingkat output maupun kesempatan kerja dan memacu pertumbuhan ekonomi.

\section{Pertumbuhan penduduk}

Pertumbuhuan penduduk dan tenaga kerja dianggap sebagai faktor positif dalam merangsang pertumbuhan ekonomi, diharapkan dengan bertambahnya jumlah tenaga kerja yang berarti dapat menambah jumlah tenaga kerja produktif, sehingga meningkatnya produktivitas tenaga kerja diharapkan dapat meningkatkan produksi, yang berarti meningkat pula pertumbuhan ekonomi (Todaro dan Smith, 2006: 93).

\section{Modal manusia}

Modal manusia (human capital) adalah istilah yang sering digunakan oleh para ekonom untuk pendidikan, kesehatan dan kapasitas manusia yang lain yang dapat meningkatkan produktivitas jika hal-hal tersebut ditingkatkan. Modal manusia dalam bentuk pendidikan maupun kesehatan mempunyai kontribusi penting dalam pertumbuhan ekonomi, dengan baiknya tingkat pendidikan diharapkan akan meningkatkan produktivitas yang selanjutnya dapat meningkatkan pendapatan (Todaro dan Smith, 2006: 434).

\section{METODE PENELITIAN \\ Data dan sumber data}

Data yang digunakan dalam penelitian ini adalah data sekunder, yaitu data yang diperoleh dengan cara, yaitu.

1. Studi kepustakaan (library study), yaitu dengan cara mempelajari berbagai literatur dan hasilhasil penelitian sebelumnya yang relevan dengan permasalahan yang diteliti, untuk memperkuat landasan teori dan mempertajam analisis.

2. Studi dokumenter (documenter study), yaitu untuk memperoleh data sekunder yang berhubungan dengan masalah penelitian. Data yang diperoleh yaitu.

a. Data PDRB Provinsi menurut lapangan usaha atas dasar harga konstan 2000 periode 2005 2009.

b. Data PDRB kabupaten/kota menurut lapangan usaha atas dasar harga konstan 2000 periode 2005-2009.

c. Data sumbangan sektor pertanian terhadap total PDRB kabupaten/kota se-Provinsi Bengkulu pada tahun 2005-2009.

d. Data indeks pembangunan manusia kabupaten/kota se-Provinsi Bengkulu pada tahun 20052009.

e. Data jumlah penduduk kabupaten/kota se-Provinsi Bengkulu pada tahun 2005-2009. 
f. Data jumlah tenaga kerja kabupaten/kota se-Provinsi Bengkulu pada tahun 2005-2009.

g. Data pengeluaran pemerintah (APBD) kabupaten/kota se-Provinsi Bengkulu pada tahun 2005-2009.

\section{Analisis Tipologi Klassen}

Alat analisis ini digunakan untuk mengklasifikasi kabupaten/kota di Provinsi Bengkulu berdasarkan rata-rata pertumbuhan ekonomi daerah pada sumbu vertikal dan rata-rata pendapatan perkapita daerah pada sumbu horizontal. Menurut tipologi Klassen, daerah dibagi menjadi empat (4) klasifikasi yaitu daerah cepat maju dan cepat tumbuh (high growth and high income), daerah maju tapi tertekan (low growth but high income), daerah berkembang cepat (high growth but low income), dan daerah relatif tertinggal (low growth and low income).

Tabel 1.3

Klasifikasi Pertumbuhan Ekonomi Menurut Tipologi Klassen

\begin{tabular}{|l|l|l|}
\hline $\begin{array}{r}\text { Laju PDRB per } \\
\text { kapita }(\mathrm{Y})\end{array}$ & \multicolumn{1}{|c|}{$\mathrm{Y}_{\mathrm{i}}>\mathrm{Y}$} & \multicolumn{1}{|c|}{$\mathrm{Y}_{\mathrm{i}}<\mathrm{Y}$} \\
\hline $\begin{array}{l}\text { Laju pertumbuan } \\
\text { ekonomi (r) }\end{array}$ & $\begin{array}{l}\text { Daerah cepat maju dan } \\
\text { cepat tumbuh }\end{array}$ & $\begin{array}{l}\text { Daerah berkembang } \\
\text { dengan cepat }\end{array}$ \\
\hline $\mathrm{r}_{\mathrm{i}}>\mathrm{r}$ & $\begin{array}{l}\text { Daerah maju tapi } \\
\text { tertekan }\end{array}$ & Daerah relatif tertinggal \\
\hline $\mathrm{r}_{\mathrm{i}}<\mathrm{r}$ & $\mathrm{P}$ & \\
\hline
\end{tabular}

Sumber: Kuncoro (2004: 118)

Keterangan:

$\mathrm{Y}=$ rata-rata PDRB per kapita kabupaten/kota

$\mathrm{Y}_{\mathrm{i}}=$ PDRB per kapita kabupaten/kota yang diamati (i)

$\mathrm{r} \quad=$ rata-rata pertumbuhan ekonomi kabupaten/kota

$\mathrm{r}_{\mathrm{i}} \quad=$ rata-rata pertumbuhan ekonomi kabupaten/kota yang diamati (i)

\section{Analisis Indeks Williamson}

Untuk mengetahui ketimpangan pembangunan antar kabupaten/kota di Provinsi Bengkulu periode 2005-2009 dapat dianalisis mengggunakan ketimpangan regional (regional in equality) yang dinamakan indeks Williamson. Indeks ketimpangan regional ini semula digunakan oleh Williamson (1965 dalam Syafrizal, 2008: 108) dengan rumus:

$$
\mathbf{I W}_{\mathbf{t}}=\frac{\sqrt{\sum\left(\mathbf{Y}_{\mathbf{i}}-\mathbf{Y}\right)^{2} \cdot \mathbf{F}_{\mathbf{i}} / \mathbf{n}}}{\mathbf{Y}}
$$

Keterangan:

$\mathrm{Iw}_{\mathrm{t}}=$ indeks kesenjangan Williamson tahun ke-t

$\mathrm{Y}_{\mathrm{i}}=\mathrm{PDRB}$ riil per kapita masing-masing daerah $\mathrm{i}$

$\mathrm{Y}=\mathrm{PDRB}$ riil per kapita provinsi

https : http://jurnal.umb.ac.id/index.php/IAKTA/index

Vol 1. No. 2. Desember 2020. Hal. 153-169 
$\mathrm{F}_{\mathrm{i}} \quad=$ jumlah penduduk di kabupaten $\mathrm{i}$

$\mathrm{n} \quad=$ jumlah penduduk provinsi

Nilai indeks Williamson terletak antara 0 sampai dengan $1(0<\mathrm{IW}<1)$, semakin mendakati 0 (nol) berarti disparitas pendapatan antardaerah semakin rendah atau dengan kata lain pertumbuhan ekonomi regional terjadi secara merata, tetapi jika indeks Williamson mendekati 1 (satu) maka disparitas pendapatan antar daerah semakin tinggi serta mengindikasikan adanya pertumbuhan ekonomi regional yang tidak merata.

\section{Regresi Data Panel}

Dalam menganalisis faktor-faktor penentu pertumbuhan PDRB per kapita digunakan model regresi data panel. Data panel atau pooling data adalah penggabungan data lintas sektoral (croos section) dan data runtun waktu (time series) untuk tujuan penaksiran suatu model regresi tertentu (Insukindro, Maryatmo, Aliman, 2001: 71). Untuk menganalisi regresi data panel digunakan Eviews sebagai alat bantu analisis dan level of significant (tingkat signifikansi) pada alpha ( $\alpha$ ) 5 persen.

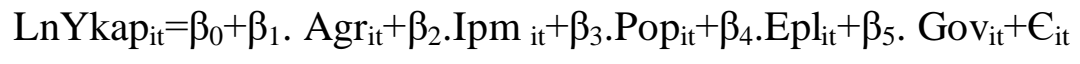

Dimana:

$\mathrm{i}=$ indeks daerah dan $\mathrm{t}$ adalah indeks waktu,

Ykap $_{\text {it }}=$ Pertumbuhan PDRB per kapita kabupaten/kota pada tahun $\mathrm{t}(\%)$

Agr $_{\text {it }}=$ Sumbangan sektor pertanian terhadap total PDRB kabupaten/kota pada tahun $\mathrm{t}(\%)$

$\mathrm{Ipm}_{\mathrm{it}} \quad=$ Indeks pembangunan manusia kabupaten/kota pada tahun $\mathrm{t}(\%)$

Pop $_{\text {it }} \quad=$ Jumlah penduduk kabupaten/kota pada tahun $\mathrm{t}(\%)$

$\mathrm{Epl}_{\mathrm{it}} \quad=$ Jumlah tenaga kerja kabupaten/kota pada tahun $\mathrm{t}(\%)$

Gov $_{\text {it }}=$ Pengeluaran pemerintah kabupaten/kota pada tahun $\mathrm{t}(\%)$

$\epsilon_{\text {it }}=$ error term

Jika penelitian menggunakan data panel maka ada 3 (tiga) teknik estimasi model dengan data panel yaitu metode OLS (common effect), model fixed effect, dan model random effect. Pendekatan common effect adalah dengan menggabungkan data time series dan cross section tanpa melihat perbedaan antarwaktu dan antarindividu, koefisien antarwaktu dan individu tetap. Pendekatan fixed effect mengasumsikan perilaku individu, maka intersep antarindividu berbeda, tetapi slope sama. Pendekatan random effect mengasumsikan variabel gangguan atau (error term) mungkin saling berhubungan antarwaktu dan antarindividu, karena adanya variabel dummy (Widarjono, 2007: 257262).

\section{HASIL DAN PEMBAHASAN}

\section{Analisis Tipologi Klassen}

Berdasarkan tipologi Klassen, kabupaten/kota di Provinsi Bengkulu periode tahun 2005 sampai dengan tahun 2009 dapat diklasifikasikan menjadi empat daerah (lihat gambar 1.1) 


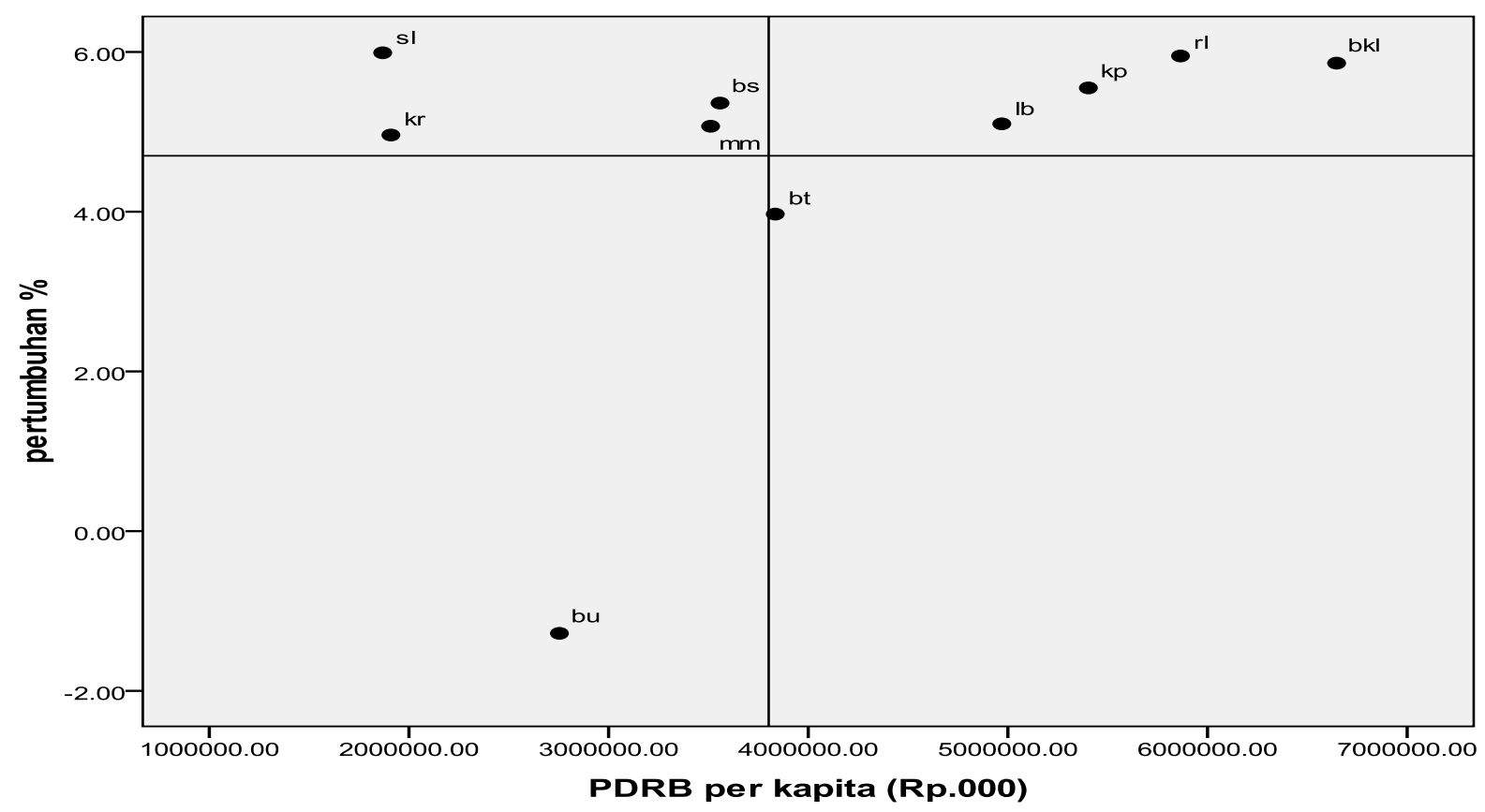

Gambar 1.1

Klasifikasi Kabupaaten/Kota di Provinsi Bengkulu Berdasakan Tipologi Klassen, 2005-2009 (data diolah, 2010)

Keterangan:

\begin{tabular}{|c|c|c|c|c|c|c|}
\hline $\begin{array}{l}\text { bs }= \\
\text { Selatan }\end{array}$ & Kab. & Bengkulu & $\mathrm{kr}=\mathrm{Kab}$ & & $\mathrm{lb}=\mathrm{Kab} . \mathrm{I}$ & bong \\
\hline $\begin{array}{l}\mathrm{rl}= \\
\text { Lebong }\end{array}$ & $\mathrm{Kab}$ & Rejang & $\mathrm{sl}=\mathrm{Kab} . \mathrm{S}$ & & $\begin{array}{l}\mathrm{kp}= \\
\text { Kepahiang }\end{array}$ & Kab. \\
\hline $\begin{array}{l}\text { bu }= \\
\text { Utara }\end{array}$ & Kab. & Bengkulu & $\begin{array}{l}\mathrm{mm}= \\
\text { Mukomuko }\end{array}$ & Kab. & $\begin{array}{l}\text { bkl = } \\
\text { Bengkulu }\end{array}$ & Kota \\
\hline $\begin{array}{l}t= \\
\text { engah }\end{array}$ & Kab. & Bengkulu & & & & \\
\hline
\end{tabular}

Dari gambar 1.1 terlihat kabupaten/kota di Provinsi Bengkulu pada tahun 2005 sampai dengan tahun 2009 dapat dibagi menjadi empat tipe daerah, yaitu.

a. Daerah yang cepat maju dan cepat tumbuh, yaitu Kota Bengkulu, Kabupaten Rejang Lebong, Kabupaten Kepahiang, dan Kabupaten Lebong.

b. Daerah yang berkembang cepat, yaitu Kabupaten Bengkulu Selatan, Kabupaten Kaur, Kabupaten Seluma, dan Kabupaten Mukomuko.

c. Daerah maju tertekan, yaitu Kabupaten Bengkulu Tengah. 
d. Daerah relatif tertinggal. Daerah yang termasuk dalam klasifikasi ini adalah Kabupaten Bengkulu Utara.

\section{Analisis Indeks Williamson}

Berdasarkan jumlah penduduk dan Produk Domestik Regional Bruto (PDRB) per kapita antarkabupaten/kota di Provinsi Bengkulu tahun 2005-2009 dapat dihitung indeks Williamson pada tabel berikut.

Tabel 1.4

Indeks Williamson dan PDRB Per Kapita Provinsi Bengkulu, 2005-2009

\begin{tabular}{|c|c|c|}
\hline Tahun & Indeks Williamson & PDRB per kapita \\
\hline 2005 & 0,38 & $3.983 .844,00$ \\
\hline 2006 & 0,38 & $4.153 .945,00$ \\
\hline 2007 & 0,39 & $4.335 .452,00$ \\
\hline 2008 & 0,44 & $4.497 .189,00$ \\
\hline 2009 & 0,39 & $4.608 .548,00$ \\
\hline Rata-rata & 0,39 & $4.315 .795,60$ \\
\hline
\end{tabular}

Sumber: BPS Provinsi Bengkulu, 2010 (data diolah)

Selanjutnya untuk melihat secara lebih jelas mengenai kecenderungan ketimpangan selama periode 2005 sampai 2009 dapat dilihat pada grafik indeks ketimpangan Williamson pada gambar 1.2 .

\section{indeks Williamson}

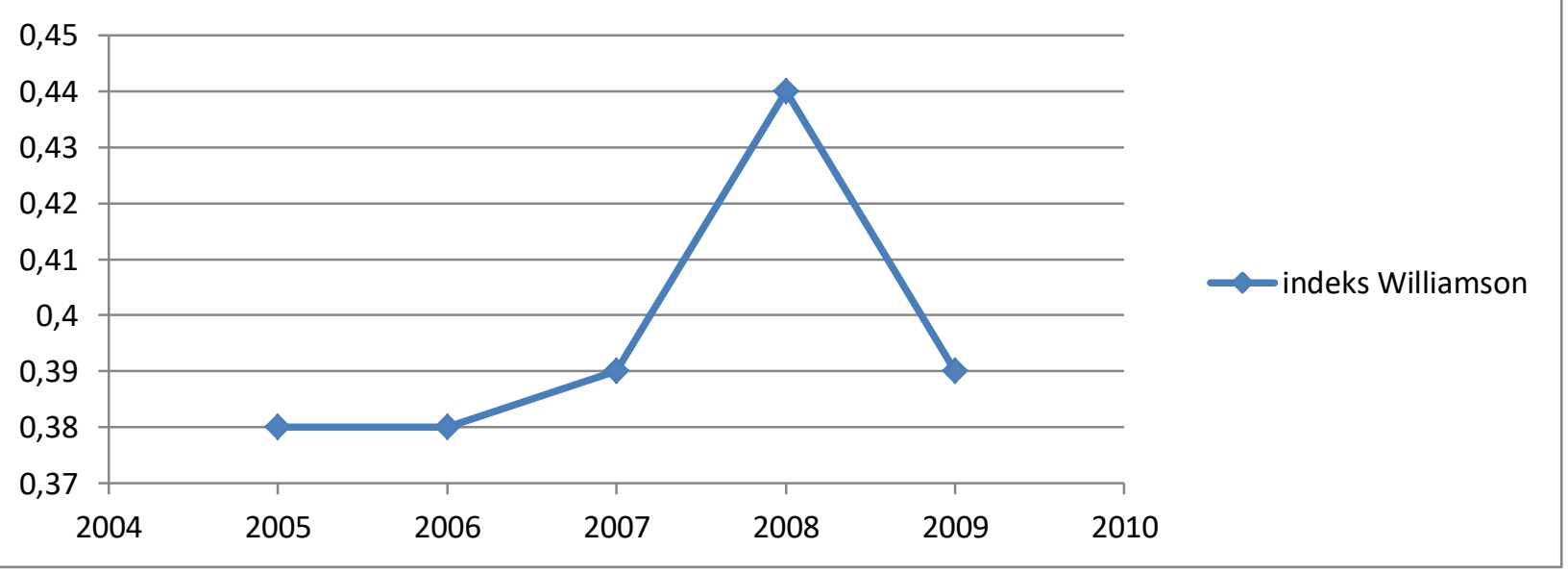

Gambar 1.2

Grafik Indeks Ketimpangan Williamson Provinsi Bengkulu, 2005-2009 (data diolah, 2010)

Kecenderungan ketimpangan antarkabupaten/kota di Provinsi Bengkulu pada periode 20052009 yang ditunjukkan oleh indeks Williamson dimana terjadi peningkatan pada tahun 2008 sebesar 0,44 sedangkan pada tahun 2009 terjadi penurunan menjadi sebesar 0,39. Secara rata-rata nilai indeks Williamson adalah sebesar 0,39 yang berarti nilai tersebut semakin menjauhi nol. Jadi, pada 
periode 2005 sampai 2009 dapat disimpulkan terdapat ketimpangan PDRB per kapita antarkabupaten/kota di Provinsi Bengkulu.

\section{Analisis Hipotesis Kuznets}

Pada gambar 1.3 memperlihatkan hubungan antara indeks ketimpangan Williamson dan pertumbuhan PDRB per kapita pada periode 2005 sampai 2009. Kurva tersebut berbentuk Uterbalik. Hal ini berarti bahwa, pada masa-masa awal pertumbuhan ketimpangan memburuk dan pada tahap-tahap berikutnya ketimpangan menurun. Kurva yang berbentuk U-terbalik ini menunjukkan bahwa hipotesis Kuznets berlaku di Provinsi Bengkulu. Dari hasil analisis korelasi Spearman antara pertumbuhan PDRB per kapita dengan indeks Williamson, didapatkan koefisien korelasi bernilai positif sebesar 0,211 dengan signifikansi sebesar 0,734. Ini berarti antara indeks Williamson dengan pertumbuhan PDRB per kapita hasil korelasinya kurang kuat secara statistik karena terbukti tidak signifikan pada $\alpha=5 \%$.

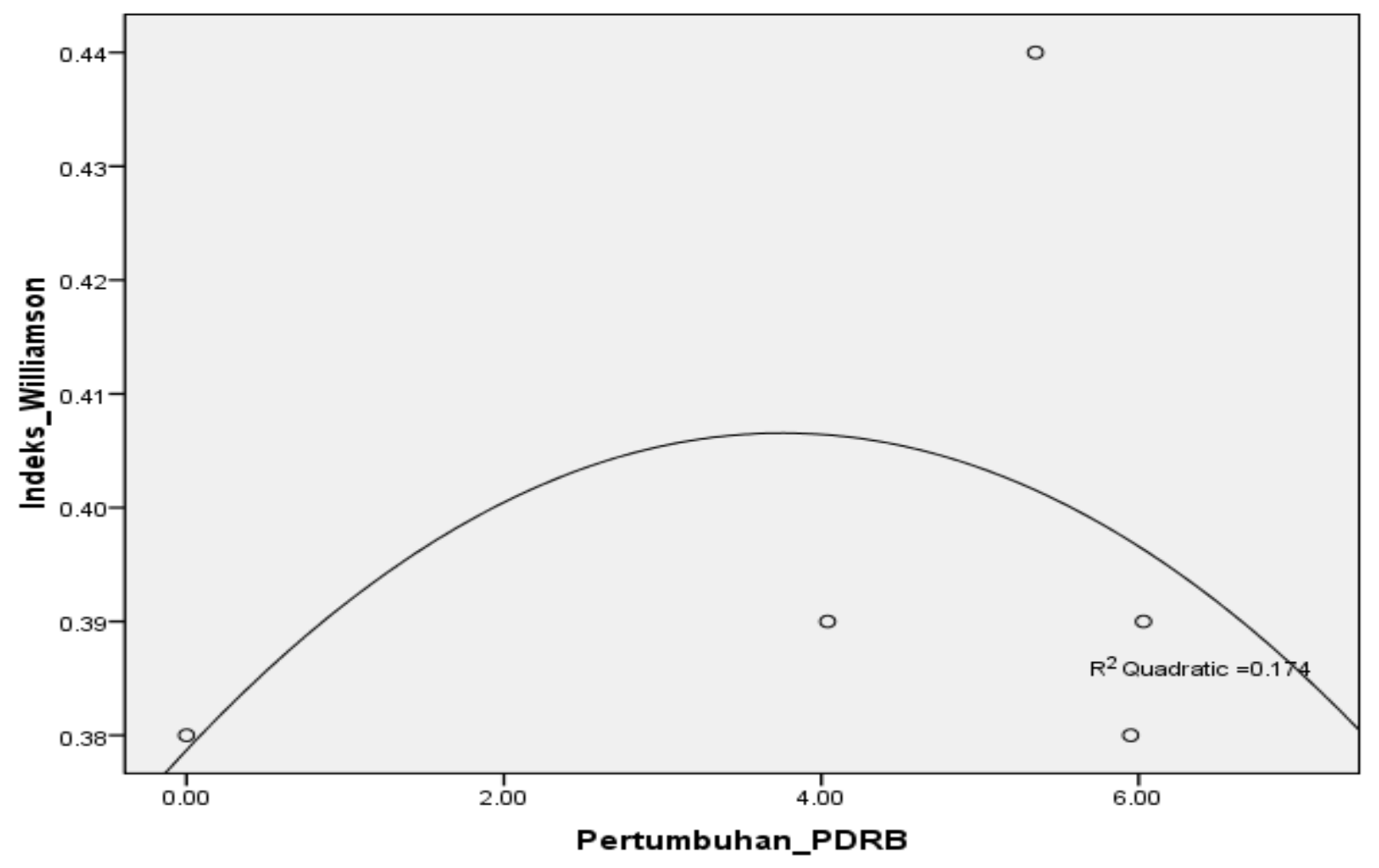

Gambar 1.3

Grafik Hubungan Antara Indeks Williamson Dengan PDRB Per Kapita Provinsi Bengkulu, 2005-2009 (data diolah, 2010)

\section{Analisis Regresi Data Panel}

Dalam melakukan estimasi regresi data panel terlebih dahulu dilakukan uji pemilihan model melalui uji Chow Test, LM Test, dan Hausman Test untuk menentukan model terbaik. Ketiga uji ini digunakan untuk memilih salah satu model terbaik dari tiga pendekatan yang ada dalam analisis data panel, yaitu pendekatan Polled Least Square (PLS), Fixed Effect, dan Random Effect. 


\section{a. Hasil estimasi model regresi.}

Berdasarkan hasil estimasi terhadap model regresi yang dipakai dan dengan menggunakan program Eviews 6.0 diperoleh nilai koefisien dan parameter tiap variabel seperti disajikan berikut ini:

Tabel 1.5

\section{Hasil Regresi Dengan Metode Fixed Effect}

\begin{tabular}{crlrl}
\hline \hline Variable & Coefficient & Std. Error & t-Statistic & Prob. \\
\hline \hline C & 8125038. & 2949463. & 2.754752 & 0.0097 \\
AGR? & 7.556954 & 2.806535 & 2.692627 & 0.0113 \\
IPM? & -84746.93 & 44091.86 & -1.922054 & 0.0638 \\
POP? & 25.96205 & 3.366195 & 7.712582 & 0.0000 \\
EPL? & -43.57362 & 4.625686 & -9.419926 & 0.0000 \\
GOV? & 0.000555 & 0.000627 & 0.885735 & 0.3826 \\
Fixed Effects & & & & \\
(Cross) & & & & \\
_BS-C & 685334.0 & & & \\
_RL_C & -2181732. & & & \\
_BU-C & -384513.6 & & & \\
_KR-C & -1111137. & & & \\
_SL-C & -1661327. & & & \\
_MM-C & -391323.4 & & & \\
_LB-C & 176305.3 & & & \\
_KPY_C & -332555.6 & & & \\
_BKL_C & 5200949. & & & \\
\hline \hline
\end{tabular}

Hasil estimasi regresi di atas maka diperoleh persamaan model regresi yang dapat ditulis dalam bentuk persamaan linear sebagai berikut. 


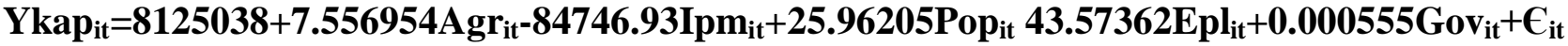

Keterangan:

Ykap = Pertumbuhan PDRB per kapita

Agr = Sumbangan sektor pertanian

Ipm = Indeks pembangunan manusia

Pop = Jumlah penduduk

Epl = Jumlah tenaga kerja

Gov = Pengeluaran pemerintah

it $\quad=$ i menunjukkan indeks daerah dan $\mathrm{t}$ menunjukkan waktu

\section{b. Uji t-statistik}

Uji t-statistik yaitu pengujian statistik terhadap parameter-parameter regresi secara individu. Hal ini membandingkan antara t-hitung dengan t-tabel, dengan tingkat signifikansi 5 persen.

Tabel 1.6

Hasil uji signifikansi

\begin{tabular}{|c|c|r|l|}
\hline Variabel & t-statistik & t-tabel & \multicolumn{1}{|c|}{ Keterangan } \\
\hline AGR & 2,692627 & 2,042 & Signifikan \\
\hline IPM & 1,922054 & 2,042 & Tidak signifikan \\
\hline POP & 7,712582 & 2,042 & Signifikan \\
\hline EPL & 9,419926 & 2,042 & Signifikan \\
\hline GOV & 0,885735 & 2,042 & Tidak signifikan \\
\hline Dengan $\alpha=5$ persen $\mathrm{n}=45$ t-tabel $=(\alpha, \mathrm{n}-\mathrm{k}) \mathrm{k}=14$ \\
\hline
\end{tabular}

Dari tabel di atas dapat disimpulkan bahwa.

a. Pertanian (Agr) secara statistik signifikan terhadap PDRB per kapita, hal ini ditunjukkan dengan nilai t-hitung $(2,692627)$ yang lebih besar dari nilai t-tabelnya $(2,042)$, maka H0 ditolak.

b. Indeks pembangunan manusia (Ipm) secara statistik tidak signifikan terhadap PDRB per kapita, hal ini ditunjukkan dengan nilai t-hitung $(1,922054)$ yang lebih kecil dari nilai t-tabelnya $(2,042)$, maka HO diterima.

c. Jumlah penduduk (Pop) secara statistik signifikan terhadap PDRB per kapita, hal ini ditunjukkan dengan nilai t-hitung $(7,712582)$ yang lebih besar dari nilai t-tabelnya $(2,042)$, maka H0 ditolak.

d. Jumlah tenaga kerja (Epl) secara statistik signifikan terhadap PDRB per kapita, hal ini ditunjukkan dengan nilai t-hitung $(9,419926)$ yang lebih besar dari nilai t-tabelnya $(2,042)$, maka H0 ditolak.

e. Pengeluaran pemerintah (Gov) secara statistik tidak signifikan terhadap PDRB per kapita, hal ini ditunjukkan dengan nilai t-hitung $(0,885735)$ yang lebih kecil dari nilai t-tabelnya $(2,042)$, maka H0 diterima.

\section{c. Uji F-statistik}

Uji F-statistik yaitu pengujian secara serempak hubungan variabel-variabel independen secara keseluruhan dengan variabel dependen, dengan membandingkan antara F-hitung dengan F- 
tabel. F-hitung yang dihasilkan adalah 149.87, sedangkan F-tabel dengan tingkat signifikansi $\alpha=5$ persen, $(\alpha,(\mathrm{k}-1)(\mathrm{n}-\mathrm{k}))$ adalah $(5 \%,(13)(31))=2,09$. Dengan F-hitung lebih besar dari F-tabelnya maka H0 ditolak, ini berarti variabel-variabel independen secara serempak dan signifikan mempengaruhi variabel dependen.

\section{d. Uji koefisien $\mathbf{R}^{2}$}

Uji koefisien $\mathrm{R}^{2}$ yaitu pengujian yang dimaksudkan untuk mengukur seberapa besar variabelvariabel independen dalam model penelitian mampu menjelaskan variabel dependennya. Dari hasil perhitungan Eviews 6.0 diperoleh hasil $\mathrm{R}^{2}$ sebesar 0,984338. Hal ini menunjukkan bahwa sebesar 98,43 persen dari variasi PDRB per kapita dapat dijelaskan oleh variasi-variasi pertanian, indeks pembangunan manusia, jumlah penduduk, jumlah tenaga kerja, dan pengeluaran pemerintah, sedangkan 1,57 persen sisanya dijelaskan dengan variabel lain di luar model.

\section{Pembahasan}

Berdasarkan hasil analisis statistik dan ekonometrika, maka pengaruh masing-masing variabel independen terhadap variabel dependen dapat dijelaskan sebagai berikut

1. Variabel pertanian (AGR) menunjukkan nilai positif dengan PDRB per kapita di Provinsi Bengkulu dimana semakin besar nilai pertanian maka nilai PDRB per kapita (Ykap) semakin besar. Nilai koefisien sebesar 7,556 menunjukkan setiap kenaikan 1 persen pertanian (AGR) maka PDRB per kapita (Ykap) mengalami peningkatan 7,556 persen.

2. Variabel jumlah penduduk (POP) menunjukkan nilai positif dengan PDRB per kapita di Provinsi Bengkulu dimana semakin besar nilai jumlah penduduk maka nilai PDRB per kapita (Ykap) semakin besar. Nilai koefisien sebesar 25,962 menunjukkan setiap kenaikan 1 persen pertanian (AGR) maka PDRB per kapita (Ykap) mengalami peningkatan 25,962 persen.

3. Variabel jumlah tenaga kerja (EPL) menunjukkan nilai negatif dengan PDRB per kapita di Provinsi Bengkulu dimana semakin besar nilai jumlah tenaga kerja maka nilai PDRB per kapita (Ykap) semakin kecil. Nilai koefisien sebesar -43,573 menunjukkan setiap kenaikan 1 persen IPM maka PDRB per kapita mengalami penurunan 43,573 persen.

\section{KESIMPULAN DAN SARAN}

\section{Kesimpulan}

Berdasarkan hasil analisis data dan pembahasan serta tujuan yang ingin dicapai pada penelitian ini, maka dapat diambil beberapa kesimpulan sebagai berikut.

1. Berdasarkan analisis Tipologi Klassen pada periode pengamatan 2005-2009 kabupaten/kota di Provinsi Bengkulu dapat diklasifikasikan berdasarkan pertumbuhan ekonomi dan PDRB per kapita menjadi empat kelompok yaitu daerah yang cepat maju dan cepat tumbuh (high income and high growth) yaitu Kota Bengkulu, Kabupaten Rejang Lebong, Kabupaten Kepahiang, dan Kabupaten Lebong. Daerah yang berkembang cepat (high growth and low income) Kabupaten Bengkulu Selatan, Kabupaten Kaur, Kabupaten Seluma, dan Kabupaten Mukomuko. Daerah maju tertekan (low growth but high income) yaitu Kabupaten Bengkulu Tengah. Daerah relatif tertinggal (low growth and low income) yaitu Kabupaten Bengkulu Utara. 
2. Dari analisis indeks Williamson selama periode 2005-2009 menunjukkan terdapat ketimpangan PDRB per kapita antarkabupaten/kota di Provinsi Bengkulu, hal ini ditunjukkan oleh angka indeks Williamson secara rata-rata menjauhi nol (0) yaitu sebesar 0,39. Kemudian analisis hipotesis Kuznets menunjukkan hubungan antara pertumbuhan PDRB per kapita dengan indeks Williamson membentuk pola U-terbalik, yang berarti bahwa hipotesi Kuznets selam periode 2005 sampai 2009 berlaku di Provinsi Bengkulu. Ketimpangan yang terjadi diakibatkan adanya perbedaan sumber daya alam, sumber daya manusia, dan juga perbedaan alokasi dana yang dipergunakan untuk pembangunan di setiap kabupaten/kota Provinsi Bengkulu.

3. Dari hasil analisis regresi data panel dengan menggunakan pendekatan fixed effect yang merupakan model terbaik dalam melakukan analsis dapat disimpulkan bahwa variabel pertanian (AGR) dan variabel jumlah penduduk (POP) berpengaruh positif dan signifikan terhadap perumbuhan PDRB per kapita. Artinya variabel tersebut mempunyai peranan penting dalam peningkatan pertumbuhan PDRB per kapita. Variabel jumlah tenaga kerja (EPL) berpengaruh negatif dan signifikan terhadap pertumbuhan PDRB per kapita. Variabel indeks pembangunan manusia (IPM) dan varibel pengeluaran pemerintah (GOV) tidak berpengaruh terhadap pertumbuhan PDRB per kapita.

\section{Saran}

Berdasarkan temuan dalam penelitian ini, ada beberapa saran yang perlu disampaikan, antara lain.

1. Kebijakan pembangunan ekonomi yang memprioritaskan pada daerah yang relatif tertinggal tanpa mengabaikan daerah yang sudah maju dan tumbuh pesat.

Dalam upaya peningkatan posisi perekonomian dari daerah relatif tertinggal menjadi daerah maju dan tumbuh pesat diperlukan pembangunan sumber daya manusia dan pemanfaatan potensi sumber daya alam secara optimal. Pembangunan sumber daya manusia dapat dilakukan dengan cara memperbaiki dan menambah fasilitas pendidikan dan fasilitas kesehatan yang telah ada selama ini, serta menggalakan kembali program-program yang dapat meningkatkan kualitas sumber daya manusia seperti program wajib belajar, dan jaminan kesehatan masyarakat. Sektor utama perekonomian daerah relatif tertinggal masih bertumpu pada sektor pertanian. Oleh karena itu, pemerintah daerah harus membangun fasilitas-fasilitas dan membuat program-program yang dapat memajukan sektor pertanian, seperti pembangunan irigasi, jalan penghubung antardaerah, dan pengembangan sektor industri pengolahan hasil pertanian.

2. Untuk mengurangi ketimpangan antardaerah pemerintah harus meningkatkan alokasi dana pembangunan kabupaten/kota setiap tahunnya dengan memprioritaskan pembangunan fisik pada bidang pendidikan, kesehatan, pertanian, perhubungan, dan juga program-program pemerintah yang pro-poor supaya pembangunan bisa berjalan serentak di seluruh wilayah Provinsi Bengkulu.

3. Beberapa program pembangunan pemerintah daerah kabupaten/kota yang harus dilakukan untuk menigkatkan pertumbuhan pendapatan per kapita seperti membangun dan memperbaiki jalan yang menuju daerah-daerah sentra produksi pertanian agar mobilitas barang dan jasa meningkat, 
memberikan bantuan modal usaha kepada petani kecil dan UMKM, memperbaiki kualitas dan kuantitas pendidikan dasar, serta memberikan program-program jaminan kesehatan masyarakat.

\section{Daftar Pustaka}

Arsyad, L. (2005). Pengantar Perencanaan Pembangunan Ekonomi Daerah. Edisi Kedua. Yogyakarta: BPFE.

Badan Pusat Statistik Republik Indonesia. (2005). Statistik Keuangan Pemerintah Daerah Kabupaten/Kota 2004-2005. Jakarta-Indonesia: Badan Pusat Statistik.

Badan Pusat Statistik Republik Indonesia. (2006). Statistik Keuangan Pemerintah Daerah Kabupaten/Kota 2005-2006. Jakarta-Indonesia: Badan Pusat Statistik.

Badan Pusat Statistik Republik Indonesia. (2007). Statistik Keuangan Pemerintah Daerah Kabupaten/Kota 2006-2007. Jakarta-Indonesia: Badan Pusat Statistik.

Badan Pusat Statistik Republik Indonesia. (2008). Statistik Keuangan Pemerintah Daerah Kabupaten/Kota 2007-2008. Jakarta-Indonesia: Badan Pusat Statistik.

Badan Pusat Statistik Republik Indonesia. (2009). Statistik Keuangan Pemerintah Daerah Kabupaten/Kota 2008-2009. Jakarta-Indonesia: Badan Pusat Statistik.

Badan Pusat Statistik Provinsi Bengkulu. (2005). Bengkulu Dalam Angka 2005. Bengkulu: BPS Bengkulu.

Badan Pusat Statistik Provinsi Bengkulu. (2006). Bengkulu Dalam Angka 2006. Bengkulu: BPS Bengkulu.

Badan Pusat Statistik Provinsi Bengkulu. (2007). Bengkulu Dalam Angka 2007. Bengkulu: BPS Bengkulu.

Badan Pusat Statistik Provinsi Bengkulu. (2008). Bengkulu Dalam Angka 2008. Bengkulu: BPS Bengkulu.

Badan Pusat Statistik Provinsi Bengkulu. (2009). Bengkulu Dalam Angka 2009. Bengkulu: BPS Bengkulu.

Boediono. (1999). Teori Pertumbuhan Ekonomi, Seri Sinopsis Pengantar Ilmu Ekonomi Nomor 4, Edisi Pertama, BPFE, Yogyakarta.

Insukindro, Maryatmo, \& Aliman. (2001). "Ekonometrika Dasar dan Penyusunan Indikator Unggulan Ekonomi”. Modul. Lokakarya Ekonometrika Dalam Rangka Penjajakan Leading Indikator Export di KTI. Makassar.

Kuncoro, M. (2004). Otonomi dan Pembangunan Daerah:Reformasi, Perencanaan, Strategi dan Peluang. Jakarta: Erlangga.

Meier, Gerald, M dan Raunch, James, E. (2005). Leading Issues in Economic Development (8 ${ }^{\text {th }}$ ed.). Oxford University Press, Inc. New York.

Sukirno, S. (1999). Pengantar Teori Makro Ekonomi (Edisi Kedua). Jakarta: PT Raja Grafindo Persada.

Syafrizal. (2008). Ekonomi Regional, Teori dan Aplikasi. Padang: Baduose.

Todaro, M, P, \& Smith, S, C. (2006), Pembangunan Ekonomi di Dunia ke Tiga (terjemahan) (Edisi Kesembilan). Jilid I. Jakarta: Erlangga.

Widarjono, A. (2007). Ekonometrika Teori dan Aplikasi untuk Ekonomi dan Bisnis (Edisi Kedua). Yogyakarta: Ekonisia Fakultas Ekonomi UII. 
Widodo, T. (2006). Perencanaan Pembangunan: Aplikasi Komputer (Edisi Pertama). Yogyakarta: UPP STIM YKPN.

Williamson, J, G. (1965). "Regional Inequality And The Process Of National Development: A Description Of The Patterns". Economic Development and Cultural Change. Vol. 13. No. 4. Part 2(Jul.,1965). 